\title{
Flexibility Models: A Critical Analysis
}

\section{Suzette Dyer University of Waikato}

\begin{abstract}
Mass production structures have been criticised as being to rigid to respond to increased global competition and to increasingly sophisticated consumers demanding differentiated products. Additionally, the job designs associated with mass production have been criticised for deskilling workers leading to high worker dissatisfaction; the inability of workers to make decisions about how they perform their jobs; and for creating a work force that is not able to respond to the requirements associated with the demands of new work practices. Thus calls for increased flexibility at the organisation level have been made by employer and employee groups. Flexibility promises to provide organisations with production systems and work organisation that will provide the competitive edge needed in an increasingly global market; and employees with increased participation, more interesting jobs, stable employment, and better wages and work conditions. However, there still appears to be many unresolved issues relating to the flexibility debate.
\end{abstract}

\section{Introduction}

Calls for flexibility in New Zealand have come from both employer and employee groups. Flexibility promises organisations the ability to become competitive in an increasingly global economy. For employees flexibility promises improved working conditions and more varied and interesting jobs. Flexibility also promises consumers high quality and differentiated products. Despite the potential gains there is no clear definition of flexibility, and therefore no agreement on the extent of the hidden costs associated with flexibility.

This paper briefly explores three prominent flexibility models with the aim of identifying the issues involved in the flexibility debate. A brief review of the literature indicates that empirical findings do not support the advantages espoused by the theoretical models of flexibility. Additionally, the three models of flexibility reviewed could not adequately explain the trends in reorganisation that are occurring.

\section{The call for flexibility}

The 1970s saw New Zealand enter a period of high and sustained unemployment, experience high interest rates and slowed economic growth. The oil shocks of the 1970ís, changing markets, and increased competition from Asia and the development of the EC have all been offered as factors contributing to the crisis that had developed in New Zealand. Work practices and the regulated New Zealand economy increasingly became criticised as being too inflexible to met the challenges of the 1980s and beyond. At the macroeconomic level, Keneysian policies that had been introduced during the post war period were increasingly became viewed as contributing to this crisis. As Bertram (1993) notes, a neo-classic revival in the Western economies saw iGovernments ... advised to step back from the attempt to secure the great aims of the post-war era: full employment, growth, and collective responsibility for social welfareî. Deregulation, decreased government spending and anti-inflationary policy, according to the New Right, would enable market flexibility that in the medium term would encourage real economic growth leading to a higher sustained standard of living for society (Bertram, 1993). The incoming Labour Government in 1984 begun a process of deregulating the New Zealand economy. The short term cost of these measures were thought to include 
possible temporary unemployment but this would be exaggerated if labour was priced above the ëmarket rateí. Thus according to 1984 Treasury briefing papers, workers needed to respond flexibly in a dynamic economy, and that if wages could not move according to the market price, (un)employment levels would (Kelsey, 1995). According to Treasury, in a dynamic market natural unemployment levels are to be expected as ì... a large number of new jobs are being opened....at the same time many old jobs are being closedî (Treasury Briefing Papers, 1984, cited in Kelsey, 1995, p. 173). In order to allow employers and employees flexibility at the firm level, the labour markets would need to be deregulated, this was achieved with the introduction of the Employment Contracts Act 1991 by the incoming National Government (Kelsey, 1995). According to the advocates, the Employment Contracts Act would enable employers and employees to negotiate mutually beneficial employment contracts that reflect market reality; enable enterprise level bargaining; reward productivity and training; encourage more responsible union activity; and in the medium term lead to higher living standards (Kelsey, 1995). Effectively, employers had achieved micro level flexibility that would enable work practices to respond to the changing economic situation.

Employee groups and behavioural scientists have also advocated for flexibility in work practices. According to Cappelli and Rogovsky (1994), specialised jobs based on scientific management do not meet the psychological needs of workers. Opportunities to widen skill bases and increase worker participation in decision making will not only help improve employee satisfaction, but also help improve organisational productivity due to decreased absenteeism, improved flexibility, and overall employee ability to contribute to work place improvement.

Despite the calls for increased flexibility at the work place level, there has yet to be a comprehensive theory that helps explain emerging patterns of flexibility, or to predict what is likely to occur in the future. Building on the work of Cooke, Etxebarria, Morris and Rodrigues (1989), Blyton and Morris (1991) suggest that five broad trends are occurring in the re-organisation of industry that indicate forms of flexibility:

1. There is a tendency for vertically integrated organisations to use sub-contractors.

2. Internationalisation is occurring through the expansion into international markets to increase market share; and, through the forming of joint ventures, mergers, and acquisitions with corporations outside of the domestic sphere.

3. There is an increase in investment in flexible automation machinery.

4. There is a new focus on satisfying customers through quality improvement and adapting products and services to customer demand using TQM and JIT methods.

5. Unskilled, semi-skilled and professionals are increasingly required to take on a broader range of tasks, and there appears to be a move toward increasing the proportion of professional workers compared to semi-skilled and unskilled workers.

Three influential frameworks that address flexibility at the organisational level include Piore and Sabelís (1984) Flexible Specialisation; Atkinsonís (1984) Flexible Firm Model; and the Lean Production model developed in Toyota, Japan. Although these three models are not exhaustive, what is distinctive is that each trend as identified by Blyton and Morris above is central to one or more of these models. The following section will review each of these models.

\section{Flexibility models}

\section{Flexible specialisation}

In the Second Industrial Divide, Piore and Sabel (1984) argue that the world has come to a trajectory in the system of production. Despite a period of post-war prosperity, Piore and 
Sabel (1984) maintain that a crisis has developed in the mass-production and mass consumption economy and that five external factors have contributed to this crisis. The five factors include: the social unrest of the 1960s and 1970s; the introduction of floating exchange rates; the first oil shock and the Russian Wheat Deal; the second oil shock of the 1970ís; and high interest rates, world recession, and the debt crisis. The combining effect of these five influences has introduced price uncertainty and intensified price competition in the world market, thus creating uncertainty in mass consumption. The uncertainty in mass consumption leads to increased risk associated with high investment in specialised long-run production equipment. In order to address the crisis, Piore and Sable suggest that organisations need to move away from the mass-production/mass consumption economy towards smaller production cycles based on flexible specialisation and a focus on niche markets. Four types of flexible specialisation can occur. Regional Conglomerates are found in specialised industrial regions with arrangements among firms based on short term contracts. The industry is coordinated by institutions that aid in the buying and selling of products and with labour relations. Community ties are considered essential to the success of Regional Conglomerates as ëculturalí standards ensure member firms maintain the industry standards in relation to price, quality, wages and working conditions. Federated Enterprises link firms through financial interest (the holding of stocks of member firms) and through social contacts, again creating a sense of community. Solar Firms and Workshop Factories differ in the size or cost involved with production. Smaller produces may work closely utilising the capital requirements of production more effectively.

Flexible specialisation has four characteristics. First, there needs to be flexibility and specialisation. Flexibility is the ability to reorganise the production processes through reorganising the components of production and this is facilitated by new computerised technology. However, the extent of reorganisation is limited by conceptual and physical constraints imposed by specialisation. Conceptual restraints arise from the community or industryís sense of shared product. Physical restraints arise because the associated organisations within an industry are geographically located within the community. The commitment of individuals and firms to specialise in a component of the industry is thought to be possible when all resources are utilised with each reorganisation and where all member organisations and employees have a claim to be included within the community. Therefore, the community of firms must create ësafety netsí to retain staff and resources during temporary displacement arising from reorganisation. The commitment to creating safety nets leads to the second characteristic of limited entry. Limited entry to the community or industry ensures that the ësafety netsí are not over burdened by ëoutsidersí. Entry into the community is based on job placement and this might be achieved through family ties and networks. Third, competition that promotes innovation is encouraged. Innovative firms are considered to gain favourable places within the industry hierarchy, that is, although placement is guaranteed, equality of placement is not. Competition between similar industries is also considered to help the innovative process. Fourth, limits to destructive competition is needed. Wages and working conditions are set within the industry to avoid competition based on cost cutting measures that could lead to ësweatingí. That is, employment security and trust are required in order for organisations and industry to remain innovative and take advantage of new technology, and for the community to remain cohesive through periods of reorganisation.

Although flexible specialisation weakens the power of labour, Piore and Sabel (1984) maintain that in the long term working conditions and wages will improve. Additionally, they argue that a new craft culture is created under flexible specialisation, thus skills of workers will increase to include conception and execution of tasks. Flexible specialisation will also increase a sense of ëcommunitarianismí as cooperation between firms facilitates the regeneration of regional economies. 
Many of the underlying assumptions of flexible specialisation have been criticised as being to simplistic. Nolan and OíDonnel (1991) point out that in order for flexible specialisation to achieve high wages and improved working conditions such production systems will require high profits. Amin (1991) points out that in Italy - where Piore and Sabel source many of the examples of flexible specialisation - small firms with less than fifteen employees (those fitting the flexible specialisation category) are not as profitable as the medium and large firms within the same industries. Rather, Amin found small firms paid up to 50\% less than other sized employers, while at the same time employees of small firms worked longer hours. Further, Amin suggests that Piore and Sabel ignore that these small firms have traditionally employed youth and women with low union representation. Thus Amin concludes that the long hours and poor wages, and not the technical know-how of workers, leads to flexibility.

Piore and Sabel argue that the mass production/mass consumption model is in crisis as a result of saturated mass markets and more discerning consumers. The underlying assumption here is that mass production/mass consumption has been the dominant production paradigm since the introduction of the ëFordí assembly line. Amin (1991) demonstrates that small firms and craft production techniques were widely used during the ëFordistí era. That mass markets are saturated ignores the intensification of capital ownership through multinational companies and the internationalisation of brand names and the associated expansion of global mass markets (Amin, 1991). Additionally, Rainnie (1991) points out that large firms have pursued niche marketing strategies for decades, and also suggest that product differentiation strategies are designed to stress customer inequalities thus legitimise luxury consumption by the ruling class. This view is shared by Nolan and OíDonnel (1991), who go on to say that niche markets ì... can be a patent source of uncertainty, insecurity, and fluctuating living standards ... a point that is seemingly lost on the most vociferous advocates of flexible specialisation...î (p. 172). Pollert (1991) also maintains that îThe niche market may be innovative, but only in the short term; the large retailer and large producer can quickly capture the product and exploit its entrenched advantage in the market placeî (p. 19).

Finally, discussion on class struggle between capital and labour is also ignored by Piore and Sabel, rather Pollert (1991) maintains ìThe sanitised portrait of post-war prosperity boom as a virtuous cycle of Fordist growth removes conflict and contradiction and the real lives of workers living in exploitative relations of production...î (p. 22). That relationships are based on a shared sense of community under flexible specialisation ignores that the means of production are still retained by business owners, and that it is labour who are displaced during reorganisation.

\section{Atkinsonís (1984) iFlexible Firmî}

The flexible firm model addresses the rigidityís associated with the rules of employment established under scientific organisation designs. Bureaucratic and Tayloristic organisational structures were designed to increase productivity and management control over workers by establishing rules and procedures, designing jobs in a scientific way, and separating conception from the execution of work thus place all knowledge of the job with management (Bartol \& Martin, 1991). Although jobs were reduced to routine tasks, the rules established by management provided some benefits to workers. Internal labour markets created career paths; while rules established in contracts and awards governing issues such as layoff decisions, promotion decisions, sick pay and leave entitlements, provided unions with bargaining power that could restrict management prerogative (Thompson \& McHugh, 1990). Flexibility at the firm level would not only help remove the rigidityís created by these rules, but also shed the costs in terms of worker benefits associated with the rules. Atkinsonís (1984) flexible firm model provides a framework based on breaking internal hierarchical labour markets by creating a ëcoreí and a peripheryí work force. The core work-force is said to be made up of highly skilled workers who are able to participate in decision making and are directly 
employed by an organisation. Such workers are provided with job security and high salaries that reflect skill level and their importance to the organisation. The peripheral work force are characterised by low wages, low job security and having little or no autonomy in their work. Three forms of flexibility are identified by Atkinson:

- $\quad$ Functional flexibility: Allows management to move workers around jobs and tasks as the need calls. Functional flexibility is associated with the ëcoreí work-force within this model and job security is exchanged for employee versatility. Functional flexibility implies increased on the job training to allow for movement, and a redefinition of working time. Thus, the working day for the core worker will reflect product or service requirements rather than traditional forms of Monday to Friday, 9 to 5. The collapsing of pay scales assists in the movement of workers around jobs and functions.

- $\quad$ Numerical flexibility: Numerical flexibility is associated with the ëperipheralí work-force within the flexible firm model. Numerical flexibility allows management to match the need for workers with the number employed and this can be achieved through the use of a variety of short term employment arrangements that include: short term contracts, part-time employment, job sharing, self employment, contracting out, homework, franchising, and agency temps.

- $\quad$ Financial flexibility: Financial flexibility allows the cost of labour, as indicated by hourly rates and contract prices, to reflect the supply of, and demand for labour. Thus compensation packages can fluctuate according to ëmarketí worth of any given labour requirement. Thus financial flexibility supports the implementation of functional and numerical flexibility.

That organisations have pursued flexibility by introducing core and periphery labour management strategies has been disputed. Rather Elger (1991) has documented incremental changes towards flexibility usually involving job enlargement and overlapping job descriptions and functions. Management priority was found to be more focused on reducing pauses in production and increasing the intensity of labour. Elger concludes:

Such priorities make intelligible the recurrent finding that managements regard the cost of training as a major constraint on flexibility whilst being unwilling to invest heavily in such training, and the persistent management aspiration for narrower (less flexible but cheaper?) training in plant specific skills.

Some of the assumptions embedded in the flexible firm model have been questioned as a result of empirical research. Ursell (1991) argues that although the flexible firm model may use different tactics, the goal of flexible firms is the same as that of management under the Fordist model - that of achieving management control over committed workers in the pursuit of profit. Thus, the commitment of core workers can be achieved by offering them job security, more varied and interesting jobs and the potential to participate in management. Commitment from periphery workers can be achieved because there is a ready pool of potential employees that are able to replace them. However, Ursell suggests that the scope of decision making associated with the core work-force is likely to be very limited thus maintaining management prerogative. Further, Ursell found budgets, performance appraisals, orientation and selection techniques being used to both monitor and control the extent of autonomy given to the core work force. Restricted autonomy associated with the core work force was also found by Whitaker (1991). Whitaker concludes:

flexibility and multi-skilling was not ëboughtí with better working conditions or enhanced job security. Instead productivity gains have been made through intensification of work, ëcoreí workers have lost discretion they once enjoyed and their employment security is now conditional on market success, rather than assured by their status as directly employed personal (p. 252). 
Additionally, Whitaker found that the threat of contracting out was a tactic used to bring about changes to working conditions and practices. These findings are supported by Whittington (1991) who studied Research and Development department scientists - a group of workers that theoretically fall into the core category. A reduction in autonomy and work intensification was achieved by exposing Research and Development department scientists to ëmarket forcesí by turning the departments into profit centres. Redundancies were made at the same time, thus job security was achieved by meeting ëmarket demandsí effectively obscuring management control. That the ëcoreí work-force achieves job security, improved working conditions and better pay is thus disputed. Not only are the benefits associated with the ëcoreí work-force challenged, but the status of the periphery work-force as opposed to the ëcoreí and in relation to the importance to the organisation achieving desired goals is also challenged.

Buultjens and Luckie (1996) found that in the hospitality industry part-time and temporary staff were extensively used to provide essential core services and that the existence of centralised bargaining systems did not prevent the practice of numerical or temporal flexibility. Sloane and Gasteen (1991) also found that the use of temporary workers was more likely to occur where demand was predictable, and that overtime was the preferred methods to achieve temporal flexibility where demand was unpredictable, thus temps were not replacing standard workers. Malloch (1991) found that the use of sub-contracting was not always used to cut costs, rather contractors often provided essential specialist knowledge that was not found in-house, and that where contractors were used, the benefits achieved through decreased overheads had to outweigh the potential costs in terms of contractor commitment, quality and control issues. Thus empirical research consistently concludes that the flexible firm model is insufficient to explain the changes observed in organisations, and that the theoretical distinction made between core and peripheral workers appears to be unsupported.

\section{Lean production}

The lean production system was developed in the Toyota Car Company in Japan. Lean production systems reduce production costs by utilising sub-contractors and Just In Time delivery systems. JIT systems rely on high quality inwards goods, close relationships with subcontracting firms, managerial involvement in work, flexible labour utilisation, multi-purpose machinery, and short set up times. Quality circles are set up to help with continuos improvement and to improve worker participation in the production process (Thompson \& McHugh, 1990). Cappelli and Rogovsky (1994) maintain that îThe lean production models basically argue that increased quality, productivity and flexibility can be achieved by making better use of employeesî (p. 207). Mathews (1994) discusses the advantages from implementing lean production systems as arising from functional flexibility within the production process allowing for quick response to customer needs; getting things right the first time thus decreasing wastage; increased worker skill and participation allowing quick and effective on the job decisions; and the ability to change rapidly to market demand due to adaptable technology and small batch production. The success associated with the Japanese car industry has in part been attributed to lean production and attempts have been made to adopt the ëJapanisationí in the United States and other countries. Womack, Jones and Roos (1990, p. 278) maintain that:

\footnotetext{
Lean production will supplant both mass production and the remaining outposts of craft production in all areas of industrial endeavour to become the standard global production system of the twentyfirst century.
}

Berggren (1993) studied both the organisations in the United States that have adopted lean production and Japanese firms operating lean production and found contradictory evidence to the extent of the benefits gained from the system. Berggren (1993) observed that there are disadvantages of lean production processes for workers. First, Berggren maintains that there is a ërelentless performance demandí where employees seldom talked to each other unless it 
was work related. Unlimited hours meant that employees could be asked to work overtime at a moments notice and that such overtime was considered the ëbufferí in lean production. Berggren maintains that the general working population in Japan is male dominated with the expectation that workers have someone else to take care of their family, in contrast the American organisations employed 30 per cent women. Third, there was a high incidence of occupational overuse syndrome resulting from the extreme pace and repetitive nature of work. Berggren observed that in Japan, OOS is not a recognised disease, while there were reports of workers in American owned Japanese firms being dismissed as a result of OOS due to their inability to perform to the speed required by lean production. Thus workers were found to be working in pain to keep their jobs. Berggren concludes that the lean production firm is a rigorous factory regime: ìUniforms are compulsory, conduct and discipline codes are spelled out in detail, the workplace is minutely regulated and all personal attributes prohibitedî (p. 178-179).

Additionally, Berggren questioned many of the assumptions embedded in the system and in contrast to the assumption that Japanese firms focus on niche markets by producing small batches, lean production relied on high volume output to remain profitable and that Japanese firms were beginning to ì... reduce the number of variations per model, slow down the modelchange cycle and standardise as many parts as possible across models...î (p. 166). Second, the nature of the relationship between the car manufacturers and the subcontractors has come under scrutiny. Turnbull (1991) suggests that the contracting firms usually pay lower wages and that while the manufactures may operate JIT, the suppliers require buffer stocks to ensure delivery of unpredictable orders. Sei (1991) also explains that in Japan contractors are required to improve performance and provide services that are not included in the contract, that is to say the contracts are virtually meaningless. That mass production has been the dominant production system is also criticised as discussed previously. Fourth, the assumption that lean production is inherently Japanese suggests that all successful Japanese firms would operate accordingly, however Milkman (1991) found that many Japanese owned organisations in California did not operate lean production, and provided low pay and low skill jobs to primarily immigrant workers. That mass markets have collapsed and that lean production will become the dominant production system in the twenty-first century in order to fulfill niche market demand is debatable, as to are the associated benefits to those directly or indirectly employed within the system.

\section{Discussion and conclusions}

Pollert (1991) argues:

The broad assumption [underlying flexibility] is that, contrary to Bravermanís (1974) thesis of a general trend towards the degradation of the labour process under capitalism, there is now a new role for enhanced skills which confer on key skill-flexible workers a cardinal role in the form of production and a core position in the workforce.

However, despite the trends in reorganisation (as identified by Blyton and Morris) Hyman (1991) suggests the flexibility debate ought to be viewed with scepticism. First, Hyman maintains that there is nothing new about segmenting the labour market with some employee groups achieving better working conditions and pay. Second, there is no evidence of a strategic commitment by organisations to implement flexible firm structures and that the notion that core workers are highly skilled while periphery workers are low skilled is oversimplified. The growth in atypical work patterns is not dramatic and primarily occurs in industries that have always used non-standard forms of employment. Additionally, Hyman suggests that the growth in small business enterprises and self employment is more indicative of recession and the failure of large organisations to provide employment, rather than the development of an enterprise culture. Flexibility, therefore, is too loosely applied. Thus Hyman poses the question that: If there is a shift in production relations is it due to flexibility? 
Pollert (1991) maintains that the flexibility debate has obscured and overshadowed important changes that have occurred with the reorganisation of production. Pollert maintains that the globalisation of production and finance are central to contemporary restructuring by large organisations. Globalisation involves relocating production leading to spatial divisions of labour and regional economies and the imposition of external controls by multinational parent companies. Additionally, globalisation involves an increase in centralisation as parent companies seek to control off-shore activities. Standardisation of production (hence of consumption) allows for continued economies of scale. Mobile finance results from deregulated money markets exposing national economies to the (mis)fortunes of the world market.

At the firm level Pollert (1991) maintains that there has been an intensification of work effort required by labour; a decrease in health and safety standards; an increase in unemployment coupled with fragmentation of employment; a move towards decentralising some areas of decision making at the same time implementing tighter controls over decisions through the use of financial mechanisms such as budgets and performance pay. Third, Pollert points out that there is a growing gap between rich and poor and a concentration of ownership of capital. The role of the state has also changed in most advanced economies. The power of the state has become more centralised; there is less focus on the welfare of citizens; employment regulation has become minimalist; and there is a decreased monitoring of organisations to ensure safe working practices.

Rather than flexibility representing a fundamental shift in the way work is organised, many believe that it is more about intensifying the control of capital over labour by using new management techniques (Smith, 1991; Pollert, 1991; Hyman, 1991). Smith (1991) argues that flexibility is better termed neo-Fordism, and that neo-Fordism is a capitalist solution to a fundamentally scientific management problem: that of utilising the knowledge of employees for the purpose of rationalisation. Management control is obscured by notions of ëmarket forcesí as Whitaker (1991) argues:

subsequent job loses and deteriorating working conditions appear to be a consequence of ëobjectiveí market laws, rather than ëmacho-managementí, for everyone knows that if a firm - or profit centre is not profitable, something has to give.

Although changes are taking place in the organisation of work, they do not necessarily constitute a paradigm shift. The attempts to develop a general theory based on flexibility to explain the changes in work organisation have not been able to capture the range of changes that have occurred. Nor have the theories put forward been able to predict or explain the consequences of flexibility on the realities of working life.

\section{References}

Amin, A. (1991). Flexible specialisation and small firms in Italy: myths and realities. In Pollert, A. (1991). (Ed.). Farewell to Flexibility? Oxford: Basil Blackwell Ltd.

Atkinson, J. (1984). Manpower strategies for flexible organisations. Personnel Management, August.

Bartol, K., and Martin, C. (1991). Management. New York: McGraw Hill.

Berggren, C. (1993). Lean production - the end of history? Work, Employment and Society, Vol. 7, No. 2, p $163-188$.

Bertram, G. (1993). Keynesianism, neo-classicism and the state. In B. Roper and C. Rudd (Eds.). State and economy in New Zealand. Auckland: Oxford University Press.

Blyton, P., and Morris, J. (1991). A flexible future: Aspects of the flexibility debates and some unresolved issues. In Blyton, P., and Morris, J. (1991). (Eds.). A flexible Future? Prospects for Employment and Organisation. Berlin: de Gruyter \& Co.

Buultjens, J., and Luckie, K. (1997). Flexibility in the hospitality industry. Proceedings of the 1997 AIRRANZ Conference, Brisbane.

Cappelli, P and Rogovsky, N. (1994). New work systems and skill requirements. International Labour Review, Vol. 133, 1993, No. 2, p. $204-220$. 
Elgar, T. (1991). Task flexibility and the intensification of labour in UK manufacturing in the 1980s. In Pollert, A. (1991). (Ed.). Farewell to Flexibility? Oxford: Basil Blackwell Ltd.

Hyman, R. (1991). Plus ca change? The theory of production and the production of theory. In Pollert, A. (1991). (Ed.). Farewell to Flexibility? Oxford: Basil Blackwell Ltd.

Kelsey, J. (1995). The New Zealand experiment: a world model for restructure. Auckland: Auckland University Press.

Malloch, H. (1991). Strategic management and the decision to subcontract. In Blyton, P., and Morris, J. (1991). (Eds.). A flexible Future? Prospects for Employment and Organisation. Berlin: de Gruyter \& Co.

Mathews, J. (1994). Catching the wave: Workplace reform in Australia. Australia: Allen \& Urwin Pty Ltd.

Milkman, R. (1991). Japanís California factories- labor relations and economic globalization. Los Angeles: Institute of Industrial Relations, University of California.

Nolan P., and OíDonnell, K. (1991). Restructuring and the politics of renewal: the limits of flexible specialisation. In Pollert, A. (1991). (Ed.). Farewell to Flexibility? Oxford: Basil Blackwell Ltd.

Piore, M., J, and Sabel, C., F. (1984). The Second Industrial Divide. New York: Basic Books.

Pollert, A. (1991). The orthodoxy of flexibility. In Pollert, A. (1991). (Ed.). Farewell to Flexibility? Oxford: Basil Blackwell Ltd.

Rainnie, A. (1991). Flexible specialisation: New times or old hat. In Blyton, P., and Morris, J. (1991). (Eds.). A flexible Future? Prospects for Employment and Organisation. Berlin: de Gruyter \& Co.

Sei, S. (1991). Is technical innovation all? A hidden meaning of social relationships behind the product development stage in Japanese automobile industry. Paper presented at the symposium ëProduction Strategies and Industrial Relations in the Process of Internationalizationí, Sendai 14 - 16 October 1991

Sloane, P., and Gasteen, A. (1991). Primary flexibility: the flexible firm and its determinants. In Blyton, P., and Morris, J. (1991). (Eds.). A flexible Future? Prospects for Employment and Organisation. Berlin: de Gruyter \& Co.

Thompson, P., and McHugh, D. (1990). Work Organisations: A Critical Introduction. London: The MacMillan Press Limited.

Turnbull, P. (1991). Buyer - supplier relations in the UK automotive industry. In Blyton, P., and Morris, J. (1991). (Eds.). A flexible Future? Prospects for Employment and Organisation. Berlin: de Gruyter \& Co.

Ursell, G. (1991). Human resource management and labour flexibility: some reflections based on crossnational and sectoral studies in Canada and the UK. In Blyton, P., and Morris, J. (1991). (Eds.). A flexible Future? Prospects for Employment and Organisation. Berlin: de Gruyter \& Co.

Whitaker, M. (1991). Towards flexibility: technical change and buyer - supplier relations in the British clothing industry. In Blyton, P., and Morris, J. (1991). (Eds.). A flexible Future? Prospects for Employment and Organisation. Berlin: de Gruyter \& Co.

Whittington, R. (1991). The fragmentation of industrial R \& D. In Pollert, A. (1991). (Ed.). Farewell to Flexibility? Oxford: Basil Blackwell Ltd.

Womack, J., Jones, D., and Roos, D. (1990). The Matcham that changed the world. New York: Macmillan. 